\title{
INFORMATION SYSTEM STRATEGIC PLANNING USING WARD AND PEPPARD FRAMEWORK AT THE REGIONAL SECRETARIAT OF BENGKAYANG REGENCY, THE ORGANIZATION SECTION
}

\author{
Angelina Agnes ${ }^{(1)}$ dan Agustinus Fritz Wijaya ${ }^{(2)}$ \\ ${ }^{1,2}$ Information Systems, Faculty of Information Technology, Satya Wacana Christian University \\ 1,2 Jalan Diponegoro N0. 52-60, Salatiga, 50711 \\ E-mail : 682017403@student.uksw.edu ${ }^{1)}$,agustinus.wijaya@uksw.edu ${ }^{2)}$
}

\begin{abstract}
The Bengkayang Regional Secretariat is a regional apparatus that has the task of formulating policies in Regional Government whose main task is to assist Assistant III in the Administration and General Affairs in institutional arrangement, organizational development, management and performance of regional apparatus. However, this research focuses on the organizational part whose task is to produce output in the form of Regent Regulations, Regional Regulations and Decrees and so on. The purpose of this research is to analyze the use of information systems and propose a number of application portfolios that can support planning and realization to improve office performance. As seen from the development, the office is still working on various tasks manually and there is no information system that supports the operational performance of the office. This information system strategic planning uses the Ward and Peppard framework supported by a SWOT analysis (Strength, Weakness, Opportunities, Threats), Value Chain (main activity and support for internal offices), McFarlan Strategic Grid (Mapping applications). Research with this method provides recommendations that have a big influence in optimizing the application of information systems and increasing the effectiveness of performance so that the vision, mission and goals of the organization can be achieved by following the increasingly rapid development of technology. Proposals for information systems that can be implemented within the next 3 years, namely eformation, SIOTAK, SI MONEV, SI SPPD and SI Staff Reference.
\end{abstract}

\section{Keyword: Information Systems, Strategic Planning, Ward and Peppard, Regional Secretariat, Application Portfolio}

\section{INTRODUCTION}

Good information system strategic planning affects the development of Information Systems (IS) and Information Technology (IT) in an organization. Organizations need to plan strategic information systems to support their main business processes and most importantly one of the keys to achieving the expected targets of an organization. Information system strategic planning is the process of identifying a computer-based information system application portfolio that will support an organization in implementing its business plan and realizing its business objectives. This planning helps organizations in choosing strategic steps that are carried out in the long term and become more focused (Wibowo, \& Wijaya, 2018). Strategic planning describes various tools, techniques, and frameworks for management to align strategic information systems with business strategies, even seeking new opportunities through the application of innovative technology (Wedhasmara, 2017). By utilizing IS and IT gives the ability to compete and increase organizational productivity.

The Regional Secretariat or what is often called the "Setda" is one of the regional apparatuses in the Regional Government. Led by a Regional Secretary who is under the leadership and is directly responsible to the
Bengkayang Regent who has the main task of assisting the Regent in formulating policies for the administration of the Regional Government, fostering working relationships with all Regional Apparatus and other organizational units. In the organization part, the implementation of the information system is still ineffective because the center that covers everything depends on the affairs in that section (Wardhana \& Tanaamah, 2019). The application of information systems and technology can accelerate and facilitate employees in data processing. However, the resulting output is still a hard file. This results in the use of applications that are not optimal and do not align with the organization's business objectives. Apart from that, competent human resources are also needed in their respective fields in an organization.(Pratama dkk,2019)

Overcoming existing constraints, strategic planning of information systems must use a methodology, because methodology is a method used to collect information or data in discovering the truth obtained. In this way can minimize the risk of failure (Firmansyah \& Purwaningtias, 2017). The Methodology approach is Ward and Peppard very suitable for strategic planning of information systems with its analytical framework and techniques that focus on business needs which include SWOT analysis, analysis Value Chain, and McFarlan 
Strategic Grid. A method that has an input stage and an output stage. (Yobel \&Sitokdana, 2020) By using this method, various factors that influence an organization, both internal and external, are analyzed to obtain a formula that becomes the basis for the formulation of a new IS and IT strategy in the form of an portfolio, which can then be used as a strategic plan. Research using this method results strategic planning that can provide a recommendations or solutions for the development and implementation that is more effective and efficient for the organization (Agnes \& Wijaya, 2020).

Previous research related to the research topic, namely with the title: "Strategic Planning Information Systems Using the Methodology Ward and Peppard (Case Study: Nusatovel Salatiga)" The results of this research obtained a proposed information system strategy for the development and implementation of IS and IT. more effective and efficient for the organization (Agnes \& Wijaya, 2020). The second study entitled "Renstra SI or IT Business Unit (Branch IT Services) Using the Method Ward and Peppard (Case Study: PT. XYZ)" illustrates that there are weaknesses in application performance. Height, major operational, and support (Susanto \& Wijaya, 2019).

\section{FOCUS AND SCOPE}

In this study, the problems include:

1. The scope of the problems that lie in how to determine the strategic planning of the information system to maximize the application of information systems in improving the operational performance of the organization.

2. The research limitation only focuses on the organizational part of the Regional Secretariat of Bengkayang Regency, West Kalimantan.

3. The results obtained will be in the form of several information system proposals and implementation plans for information system proposals that will be made over the next 3 years with many considerations in terms of budget and time.

\section{MATERIALS AND METHODS}

The research conducted at the Organization Section, the Bengkayang Regency Regional Secretariat, used several methods in data collection or writing. At the writing stage, the qualitative descriptive research method and document study. Qualitative descriptive is a research method in which data is obtained by analyzing the business conditions and IS and IT in an organization according to the situation as it is when the research is being carried out. This research method seeks to describe the appropriate steps in formulating an information strategic planning. As stated by Sugiyono is a qualitative research method for obtaining in-depth data, data that contains meaning. Document study is a data source that is used to complement the research process whose data collection techniques are by collecting and studying the documents needed as information data through notes in an organization and looking at existing structures. Documents are records of past events in the form of writings, pictures, or monumental works of a person (Firmansyah \& Purwaningtias, 2017).

The technique of collecting data was through observation and interviews with Ms. Polina with the position of staff in the organization section of the Bengkayang Regional Secretariat. Based on the collected data, an analysis of business requirements and IS and IT was carried out, mapping of applications and the output of the analysis process in the form of information systems strategic planning proposals (Ufie, 2011).

The process of identifying problem stage is analyzed with SWOT analysis, analysis Value Chain, and McFarlan Strategic Grid to compile an IS and IT strategic plan so that it can provide information system recommendations and can be implemented.

\subsection{Strategic Planning}

Strategic planning is a management tool used to manage current conditions to project conditions in the future, so that strategic plans are a guide that organizations can use from their current conditions to work towards the next 5 to 10 years.

\subsection{Information Systems Strategy and Technology Strategy Information}

Information systems are combination of information technology and the activities of people who use technology to support operation and management. Information technology is a technology is a technology used to process data in various ways to produce quality information. Earl distinguishes between IS and IT strategies (Setiawan \& Beni, 2012). The IS strategy emphasizes on determining the information system application needed by the organization. The essence of an IS strategy is to answer the question "what?". Meanwhile, the IT strategy emphasizes the selection of technology, infrastructure, and specific skills related to or answering the "how?" Question as shown in figure 1. 


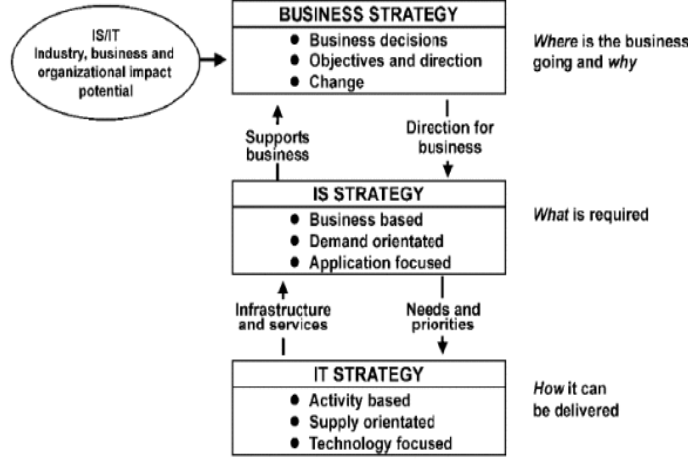

Figure 1. Relationship between Business Strategy, IS Strategy, and IT Strategy

\subsection{Information Systems Strategic Planning}

Information systems focus on how organizations can maximize the application of information technology in their business processes. Strategic system design which contains how the system will be able to help the organization's business activities so that it fits the strategy. Because without proper planning, the application of information technology does not match expectations. The importance of strategic planning for information systems is the creation of a system so that it can support existing processes within the organization and the organization can control the business, the technology that is the means in it.

\subsection{Ward and Peppard's Method}

The methodological approach starts with an analysis of the business conditions and IS and IT that have been running but is considered ineffective, then analyzes the external business conditions whether the utilization of IS and IT is maximized. Sometimes IS and IT is underutilized because it is more focused on the technology itself, not based on the organization's business needs.

The IS and IT strategic planning stage consists of an input stage and an output stage as shown in figure 2.

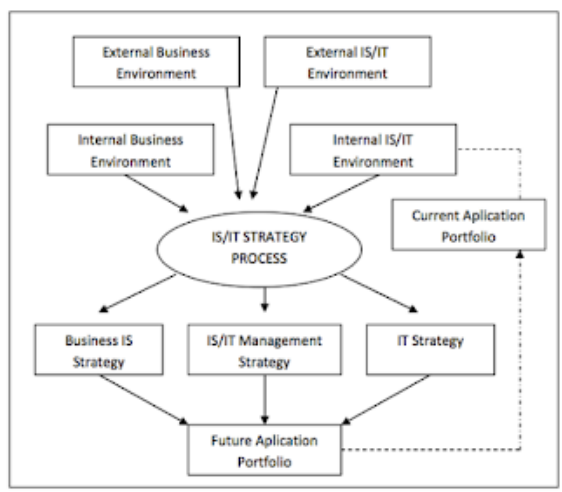

Figure 2. The IS and IT Strategic Planning Model
The input stages consist of:

1. Analysis of the internal business environment, which includes aspects of the current business strategy, objectives, resources, processes and culture of the organization's business values.

2. Analysis of the external business environment, covering the competing aspects of other firms.

3. Analysis of the internal IS and IT environment, covering the IS and IT state of the organization from the current business perspective.

4. Analysis of the external IS and IT environment, which includes technology trends and opportunities for utilization, as well as IS and IT use customers and suppliers.

While the output stage is part of what is done to produce an IS and IT strategic planning document which consists of:

1. Business IS strategy, which includes how each business unit / function will utilize IS and IT to achieve its business goals, application portfolio and information architecture overview.

2. IT strategy, which includes policies and strategies for the management of IS and IT technology and human resources.

3. The IS and IT Management Strategy, which includes common elements applied through the organization, to ensure consistency in the implementation of the required IS and IT policies.

\section{DISCUSSION}

Internal and external business environment analysis is preceded by identifying the organizations vision and mission, here is the description.

\subsection{Organization Profile}

The regional secretariat certainly has a vision and mission because it's a regional apparatus, here is the vision and mission of this organization.

1. Vision

"The realization of good governance with the support of bureaucratic reform in all fields, accountability and insightful human resources (HR)".

2. Mission

1) Realization of Good and Clean Development and Administration.

2) The creation of comprehensive and comprehensive regional laws and regulations in the context of upholding the rule of law.

3) The realization of transparent and accountable village administration and finance.

4) The realization of an economy based on the potential of regional resources, increasing competitiveness and contributing to the community and regional income.

5) The realization of the implementation and improvement of services for the procurement of 
goods / services, monitoring, control, evaluation and reporting of development results.

6) The realization of Social Welfare and Community Empowerment.

7) The realization of clean and authoritative implementation of public service affairs, personnel affairs, leadership administration, and regional financial affairs as well as the smoothness of leadership duties in Pontianak.

8) Realization of Regional Heads of Household Affairs and Regional Secretariat, Community and Equipment Supported by Professional, Accountable Administration and Administration of Regional Assets and Optimal Utilization of Regional Assets.

9) The creation of an effective, efficient and accountable regional administration and administration management.

10) The implementation of protocol activities to be smooth, orderly and safe.

11)Implementation of Economic Development Efforts, Optimization of Local, Social and Cultural Potentials, Increased Development Cooperation and Security Supervision and Availability of Regional Facilities and Infrastructure in Border Areas.

In determining IS and IT strategic planning using the method Ward and Peppard, several main steps are needed, namely:

\subsection{Internal and External Business Environment Analysis}

Internal business environment analysis identifies what needs to be improved, maintained, develops and analyzes the external environment as what can be done with the most appropriate strategies.

In the information system strategic planning, the first stage is carried out in analyzing the internal and external business environment, namely by means of a SWOT analysis tool (Strengths, Weaknesses, Opportunities, and Threats). SWOT analysis is used to analyze the strengths, weaknesses, opportunities and threats faced by the organization against internal and external conditions.

\subsubsection{SWOT Analysis}

As is known, SWOT analysis is a strategic planning analysis method used to monitor and evaluate and analyze the strengths, weaknesses, opportunities and threats that are within an organization. Here is a sample of the SWOT analysis illustration diagram found in figure 3 .

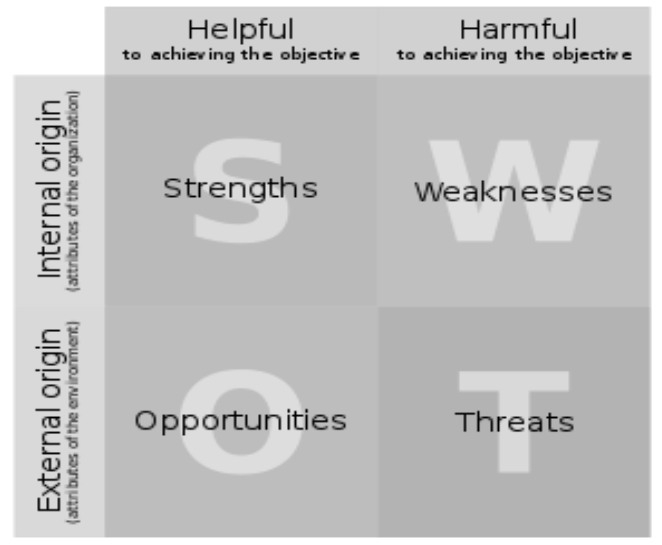

Figure 3. SWOT Analysis Model

1. Strengths

1) Element of assistant Regent

2) Protected by Regional Regulations and Bengkayang Regent Regulations.

3) Serve as drafting regulations whose output is in the form of Regional Regulations (Perda), Regent Regulations (Perbup) and Decree (SK).

2. Weakness

1) Has not been fully adequate human resources both quality and quantity due to your every need.

2) The distribution of tasks is not evenly distributed due to the lack of human resources.

3) Budget that is not calculated for building and developing an office information system.

4) Inadequate facilities and infrastructure.

3. Opportunities

1) There is a legal basis in the formulation of regional policies.

2) Additional employees to overcome work process delays due to insufficient human resources.

3) There is a good relationship and positive support from the Central Government and the Provincial Government to the District Government.

4. Threats

1) The other part owns the HR or IT staff of at least one person.

2) Inadequate optimization of the coordination mechanism in the work process between regional apparatuses.

3) There are changes to certain regulations.

4) The rapid development of information technology and the increasing use of information systems requires a quick response or keep up to date in terms of work processes in the office.

\subsubsection{Value Chain Analysis}

Strategic planning of information systems in the bag. The Regional Secretariat organization defines its business process with a Value Chain Analysis, where in this process it identifies the main activities and assistance at the office. The following is illustrated using Porter's Value Chain Activity found in figure 4. 


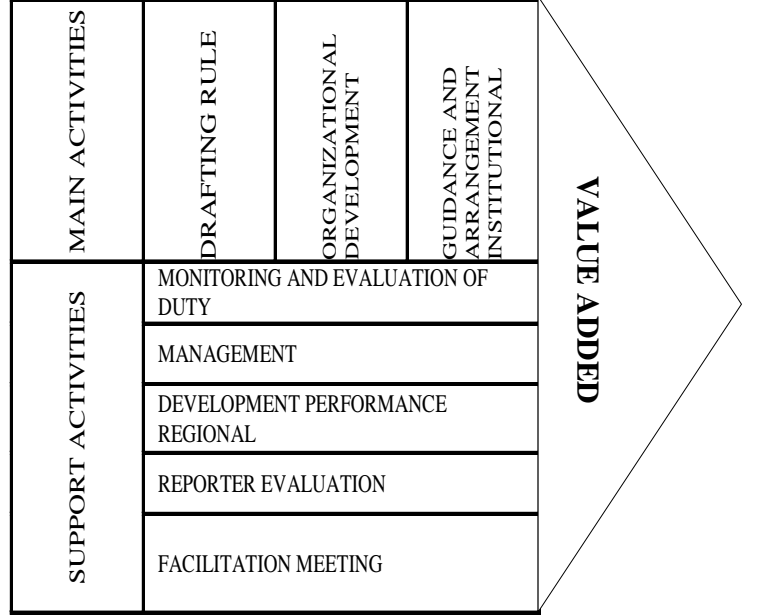

Figure 4. Value Chain Diagram of the Regional Secretariat Organization Section

1. Main Activity

The main activities at the office include:

1) Preparation of flow regulations starting with collecting materials or requesting data from agencies and agencies, the data is processed by the organization's sub-division for policies / regulations resulting in output in the form of local regulation, regional regulation and decree.

2) Organizational development aims to change a regulation in the regional apparatus according to existing regulations. The stage of collecting data from regional apparatus, analyses, and compiled by its division.

3) Guidance and Institutional Arrangement, fostering and evaluating the institution if there is something wrongs then the regulations will be drawn up, the stage is structuring-preparation-evaluation and coaching.

2. Supporting Activities

Supporting activities at the office include:

1) Monitoring and Evaluation of the Implementation of Tasks, superiors provide direction to conduct evaluations related to whether or not the implementation of the tasks that has been carried out is appropriate.

2) Management is more about the preparation of regulations such as public services and SOP.

3) Development of Regional Apparatus Performance is carried out by the division in evaluating the position whether the person's position is in accordance with the performance.

4) Report Evaluation, when the preparation has been carried out and structured, all staff will evaluate the report in order to find out whether there is something that needs to be improved or not.

5) Meeting facilitation, the organization section prepares facilities and infrastructure, if there is a change in regional apparatus it will be directly handled or discussed by the organizational division.

\subsection{Internal and External IS Environment Analysis}

IS environmental analysis is used to see the IS and IT condition in the office and there is 1 application that is owned by the bag. The Regional Secretariat organization is an e-formation information system. The e-formation information system is used by employees who are the operators and the center in the ministry as servers.

The current state of technological development is very necessary for offices using web, desktop and mobile-based IS in their business processes to increase effectiveness and efficiency. The aim is to find out what strategies are appropriate in competing in the trend of IS and IT usage.

\subsection{IT Strategy}

This IT strategy has been implemented in offices and some have used information technology for their business activities, including daily operations at the office using computers, e-mail, and the internet, which help business processes in the office run optimally. However, the condition of inadequate human resources, especially in the IT field, is very worrying and to avoid it, at least have technicians who can solve problems in the system so as not to wait from the center.

\subsection{Information System Business Strategy}

Information system a business strategy is needed in order to be able to implement an information system that can maximize achievement in realizing the vision, mission and goals. Based on several analyzes that have been carried out related to information system in the office, the resulting information system business strategy recommendations are as follows:

1. Upgrading e-formation

2. Planning and making SIOTAK

3. Planning and making SI MONEV

4. Planning and making SI SPPD

5. Planning and making SI Employee Presence

\subsection{IS and IT Management Strategy}

Based on the analysis that has been done, IS and IT management strategy planning is an ideal reference to be achieved in the strategic planning of the information system to be built. The office does not yet have an IT division, because with the IT division, it can be directly maintained without having to go to the center first. So the planning will run well and optimally if the implementation of IS and IT is supported by competent IT human resources in controlling hardware and software in the office 


\subsection{Proposal for Information Systems}

After analyzing several stages with an analysis of the systems owned by the office, the stages of proposing information systems are capable of adding to and supporting existing systems so as not to do manual work. It looks like the one shown in the following table 1.

Table 1. Proposed Regional Secretariat of Organization Information System

\begin{tabular}{|l|l|l|l|}
\hline No & $\begin{array}{l}\text { Name Information } \\
\text { System }\end{array}$ & User & $\begin{array}{l}\text { Application } \\
\text { Type }\end{array}$ \\
\hline 1 & e-formation & Admin & Web \\
\hline 2 & SIOTAK & Admin & Web \\
\hline 3 & SI MONEV & Officer & Web \\
\hline 4 & SI SPPD & Admin & Web \\
\hline 5 & $\begin{array}{l}\text { SI Employee } \\
\text { Presence }\end{array}$ & Employee & Web \\
\hline
\end{tabular}

With the application analysis McFarlan to find out the role of the application used by the bag. The Regional Secretariat organization is mapped into 4 quadrants. Based on this analysis, an application portfolio can be compiled where this process produces a documentation of the overall planned application analysis so as to take advantage of the IS and IT potential in achieving more optimal performance as in the following table 2.

Table 2. Application Portfolio

\begin{tabular}{ll}
\hline STRATEGIC & HIGH POTENTIAL \\
\hline SIOTAK & SI SPPD \\
SI MONEV & \\
e-formation & SI Employee Presence \\
\hline KEY OPERATIONAL & SUPPORT \\
\hline
\end{tabular}

1. Strategic Quadrant

The strategic quadrant contains two information system proposals, namely SIOTAK and SI MONEV. Both of these information systems have a critical influence on the success of the office in the future and give the office a competitive advantage. SIOTAK or Organizational Information System, Management and Apparatus Policy functions to assist in the accessibility data presented to users of information which contains the vision and mission, organizational structure charts such as the structure of the regional secretariat, inspectorate, sub-district, sub-district and so on. Regulations of the Head of Duties and Functions, Regional Regulations and regulations contained in this information system, the SOP of the Regional Secretariat. Meanwhile, SI MONEV or Information System for Evaluation Monitoring Reports is an information system that can assist in reporting data for each of the existing sections, compiling and presenting reports that will be more effective and efficient because of the various forms of reports that suit your needs.

2. Key Operational Quadrant

The key operational quadrant is an application used by offices at this time and can support the continuity of its activities. The application contained an e-formation where its function is to fill in employee job descriptions, employee needs, data for employee submissions or civil servant information. However, trouble occasionally occurs, especially on the internet network that interferes with activity while inputting and an error will occur in the data, the data is not lost but changes.

3. The High Potential Quadrant

The high potential quadrant is the quadrant where this application may be important to achieve the goals that exist in the office in the future. SI SPPD or Official Travel Order Information System is an information system that is used to facilitate admins in the process of making assignment orders and SPPD as well as the process of making reports for employees who are going on an official trip so they do not use manual methods. Another goal is also to make it easier to find data on employees who travel on business if the data storage uses a database.

4. Quadrant Support

Quadrant support is an application that supports but does not provide a competitive advantage, useful for improving the efficiency and effectiveness of management in the office. There is Employee Presence SI which is useful for recording the attendance of each employee by capturing photos (faces), this information system makes it very easy and saves time for all office employees.

\subsection{Application Gap Analysis}

This analysis aims to achieve a state that must be done by determining which applications will be updated, deleted and planned as in the following table 3 .

Table 3. Gap Analysis of Application

\begin{tabular}{|l|l|l|l|}
\hline $\begin{array}{l}\text { Information } \\
\text { System Proposed }\end{array}$ & Upgrade & Delete & Planning \\
\hline e-formation & $\checkmark$ & - & - \\
\hline SIOTAK & - & - & $\checkmark$ \\
\hline SI MONEV & - & - & $\checkmark$ \\
\hline SI SPPD & - & - & $\checkmark$ \\
\hline $\begin{array}{l}\text { SI Employee } \\
\text { Presence }\end{array}$ & - & - & $\checkmark$ \\
\hline
\end{tabular}

The application gap analysis determines several proposed applications to be updated, namely the eformation information system and SIOTAK information system planning, SI MONEV, SI SPPD and SI Employee Presence.

\subsection{Information System Implementation Plan}

Implementation plan of information system proposal that will be made during the next 3 years with many considerations in terms of budget and time as in the following table 4 . 
Table 4. Implementation Plan

\begin{tabular}{|l|l|l|l|l|}
\hline $\begin{array}{l}\text { IS/IT } \\
\text { Solution }\end{array}$ & 2020 & 2021 & 2022 & 2023 \\
\hline $\begin{array}{l}\text { e- } \\
\text { formation }\end{array}$ & $\begin{array}{l}\text { Key } \\
\text { Operational }\end{array}$ & & & \\
\hline SIOTAK & & Strategic & & \\
\cline { 1 - 2 } $\begin{array}{l}\text { SI } \\
\text { MONEV }\end{array}$ & & Strategic & & \\
\hline SI SPPD & & & $\begin{array}{l}\text { High } \\
\text { Potential }\end{array}$ & \\
\hline $\begin{array}{l}\text { SI } \\
\text { Employee } \\
\text { Presence }\end{array}$ & & & & Support \\
\hline
\end{tabular}

This implementation plan is within the next 3 years. In the first stage in 2021, namely SIOTAK and SI MONEV, which have a critical influence on offices, are included in the strategic quadrant category, the second stage in 2022, namely SI SPPD which may also be important in the future is categorized in the high potential quadrant and the last is the third stage. In 2023 SI Employee Presence is categorized in the support quadrant because it is a supporting application in the office and does not provide benefits for the office.

\section{CONCLUSION}

Based on the research that has been done with several stages of strategy analysis and the business environment, both internally and externally, it can be concluded that the application of information systems in the office has not been optimal, thus hindering the development of IS and IT use. This strategic planning has resulted in 5 proposals for information systems, namely e-formation, Monitoring and Evaluation Information Systems, Information Systems for Official Travel Orders, Information Systems for Employee Attendance, Organizational Information Systems, Management and Apparatus Policies. The information system recommendations can be developed and implemented within the next 3 years in the form of a portfolio of applications that can increase the effectiveness of organizational performance in order to achieve the vision, mission, goals and objectives of the organization.

\section{SUGGESTION}

This research only compiles strategic planning to recommend some information system proposals for the organization in the future, but it is better if it is implemented if it is seen from the lack of optimization of the existing information system application, because it had a big influence on the needs of the organization's information system.

\section{REFERENCES}

Agnes, A., \& Wijaya, A. F. 2020. Information Systems Strategic Planning using the Ward and Peppard Methodology (Case Study: Nusatovel Salatiga). Journal of Information Systems and Informatics, 2 (2), 246-255.

Firmansyah, Y., \& Purwaningtias, D. 2017. Analysis of Ward \& Peppard's Methodology in Determining IS and IT Strategic Planning. Cybernetics, 1(02), 70.

Pratama, A., Rizky A, V., Wigusti, R. N., \& Taqiya, N. A. 2019. Strategic Planning of Information Systems in the Aptika Sector of the Communication and Informatics Office of East Java Province. Journal of Information Systems and Smart Business (SIBC), 12 (1). 23-32.

Setiawan, A., \& Beni, I. 2012 "Strategic Planning of Information Systems in Publishing Companies with the Ward and Preppard Method: A Case Study at the Science Engineering Publishers Bandung. 11(3), 308-325.

Susanto, I. G., \& Wijaya, A. F. 2019. IS or IT Business Unit (Branch IT Services) Strategic Plan Using the Ward and Peppard Method (Case Study: PT. XYZ). J. SITECH Sist. Inf. and Teknol, 2(1), 1-12, doi: 10.24176/sitech.v2i1.3053.

Ufie, A. 2011. Local wisdom (local wisdom) Ain Ni Ain Culture of the Kei Community as a Learning Source for Local History to Strengthen Students' Social Cohesion. Repository.Upi.Edu, 39-55.

Wardhana, D. S., \& Tanaamah, A. R. 2019. Strategic Planning of Information Systems Using the Ward Andd Peppard Method Case Study of Cv XYZ. Aiti, 16(1), 18-30, doi: 10.24246/aiti.v16i1.18-30.

Wedhasmara, A. 2017. Steps for Information Systems Strategic Planning Using the Ward and Peppard Method. Journal of Information Systems, 1(1), 1422.

Wibowo, F., \& Wijaya, A. F. 2018. IS and IT Strategic Planning Using the Ward and Peppard Method (Case study: GKJ Synod). National Seminar on Indonesian Information Systems.

Yobel, E. C. C., Sitokdana, M. N. N. 2020. Strategic Planning for Information Systems Using the Ward and Peppard Method at PT Pura Barutama Company (Unit PM1O). SEBATIK 1410-3737 